\title{
Productivity and Nutrient Quality of Some Sorghum Mutant Lines at Different Cutting Ages
}

\author{
R. E. Puteri, P. D. M. H. Karti ${ }^{*}$, L. Abdullah, \& Supriyanto \\ Department of Nutrition and Feed Technology, Faculty of Animal Science, Bogor Agricultural University \\ Jalan Agatis, Kampus IPB Darmaga IPB, Bogor 16680, Indonesia \\ (Received 26-09-2014; Reviewed 23-10-2014; Accepted 07-07-2015)
}

\begin{abstract}
The objective of the study was to explore the appropriate cutting age to produce optimal biomass and good nutrient quality from sorghum mutant lines BMR i.e., PATIR 3.5 M7, PATIR 3.6 M7, and PATIR 3.7 M7, also SAMURAI I (M17). A completely randomized in Split Plot design with 2 factors and 3 replicates was used. The first factor was the type of sorghum (SAMURAI I M17, PATIR 3.5, PATIR 3.6, PATIR 3.7) as the main plot and the second factor was the cutting age $(85,95,105)$ as a subplot. Parameters observed were the production of stems, leaves, grains, total biomass production, ash, crude fat, crude fiber, crude protein, NFE, TDN, percentage of DMD, OMD and N-NH . Data were analyzed by using ANOVA followed by DMRT (Duncan Multiple Range Test). The results showed that there were highly significant interactions $(P<0.01)$ between cutting age and type of sorghum in production of stems, leaves, grains, total biomass production, value of TDN, DMD, OMD, and $\mathrm{N}-\mathrm{NH}_{3}$. Increasing cutting age significantly increased the percentage of ash content, crude protein and crude fat. The sorghum type significantly affected crude fat content nonBMR sorghum variety of SAMURAI I (M17) and achieved optimal biomass production and nutrient content at cutting age of $85 \mathrm{~d}$ similar to BMR sorghum mutant lines PATIR 3.6 and PATIR 3.5, whereas BMR sorghum mutant lines of PATIR 3.7 achieved optimum production at the age of $95 \mathrm{~d}$ of cutting. All types of sorghum varieties was not recommended to be harvested at $105 \mathrm{~d}$. Biomass production increased with the increasing of cutting age, but the nutrient content decreased.
\end{abstract}

Key words: cutting age, mutant, sorghum

\section{ABSTRAK}

Penelitian ini bertujuan untuk mencari umur pemanenan yang tepat untuk menghasilkan biomassa dan kandungan nutrien yang optimal dari galur sorghum hasil mutasi yang disebut BMR, yaitu PATIR 3.5 M7, PATIR 3.6 M7, dan PATIR 3.7 M7 serta sorghum dari varietas SAMURAI I (M17). Penelitian ini menggunakan rancangan acak lengkap pola petak terbagi dengan 2 faktor dan 3 ulangan. Faktor pertama adalah jenis sorghum (SAMURAI I M17, PATIR 3.5, PATIR 3.6, PATIR 3.7) sebagai petak utama dan faktor kedua adalah umur pemanenan $(85,95,105)$ sebagai anak petak. Peubah yang diamati ialah produksi batang, daun, bulir, produksi biomassa total, kadar abu, lemak kasar, BETN, serat kasar, protein kasar, TDN, KCBK, KCBO, serta $\mathrm{N}$-amonia. Data dianalisis dengan ANOVA diikuti dengan uji lanjut DMRT (Duncan Multiple Range Test). Hasil penelitian menunjukkan terdapat interaksi yang sangat nyata $(P<0,01)$ antara umur panen dan jenis sorghum pada produksi batang, daun, bulir, produksi biomassa total, nilai TDN, KCBK, KCBO, dan konsentrasi $\mathrm{N}$-amonia. Umur panen berpengaruh nyata pada persentase kandungan abu, protein kasar dan lemak kasar, ketiganya menurun seiring dengan bertambahnya umur panen. Jenis sorghum berpengaruh nyata pada kandungan lemak kasar. Sorghum nonBMR varietas SAMURAI I (M17), sorghum BMR PATIR 3.6 dan PATIR 3.5 mencapai produksi biomassa optimal dan kandungan nutrisi optimal pada umur panen 85 hari, sedangkan sorghum BMR PATIR 3.7 pada umur panen 95 hari. Semua jenis sorgum tidak disarankan untuk dipanen pada umur 105 hari. Produksi biomassa meningkat seiring dengan bertambahnya umur panen sedangkan kandungan nutrisi menurun.

Kata kunci: umur panen, mutan, sorghum

*Corresponding author:

E-mail: pancadewi_fapetipb@yahoo.com 


\section{INTRODUCTION}

Forage is the main source of ruminants feed used for basic living and production. Therefore, the quality, quantity and continuity of forage need to be considered. The problem of highly land conversion can cause narrowness in forage planting process. In addition, the condition of the land and the climate are also factors causing low forage production in several regions in Indonesia. It may indirectly affect the availability of feed. Regarding these problems it is necessary to explore the possibility of forage production with high productivity.

Sorghum is one of the potential forage to be developed in Indonesia. Sorghum is a cereal plant belonging to the Gramineae family. Sorghum has been developed in Africa, Asia and America countries. According to Godoy et al. (2013) and Vasilakoglou et al. (2011) this plant has a good adaptability to the conditions of marginal land.

Sorghum has been widely used for biofuels, food and also for animal feed (Godoy et al. 2013). Several studies report that sorghum is commonly used to substitute corn in livestock diet. Not only seeds, other parts of the sorghum are actually potential to be used as animal feed. In some developed countries sorghum has been used as animal feed. Forage of sorghum is generally raw material to be processed into silage.

Regarding to the potential use of sorghum which quite large, some researchers began to develop some sorghum varieties to improve production and quality of sorghum. Currently in Indonesia there are many sorghum mutant lines that are being developed. These sorghums are resulted from mutation breeding technique and have low lignin trait genotype and high dry matter digestibility (Dann et al., 2008). In the future, it is expected that these sorghums can be more superior both in terms of productivity and nutritional value. Cutting age is one factor that affects the quality and productivity of forage, so appropriate cutting age is expected to produce optimum biomass and nutritive value of sorghum.

The objective of this study is to explore the appropriate cutting age to produce optimal biomass and good nutrient quality from sorghum mutant lines of Brown midrib (BMR) consisting PATIR 3.5 M7, PATIR 3.6 M7 and PATIR 3.7 M7.

\section{MATERIALS AND METHODS}

This study was conducted from September 2013 to June 2014 in several locations, the experimental station of University Farm IPB, Faculty of Animal Science IPB for Proximate analysis, Soil Research Institute, Bogor for soil analysis, and laboratory of dairy cattle, Faculty of Animal Science IPB for digestibility analysis.

The material used in this study were the seeds of sorghum type I SAMURAI M17 as control, and sorghum mutant lines of Brown midrib (BMR) consisting PATIR 3.5 M7, PATIR 3.6 M7 and PATIR 3.7 M7. Those sorghum seeds were planted in the field.

The plot size was $4 \times 5 \mathrm{~m}$. The total number of plot was 36 consisting of 4 (sorghum) x 3 (cutting age) $\times 3$ (replications). The harvesting for cutting age treatment was done for every plot. Seed planting was done on the top ridge in $60 \times 20 \mathrm{~cm}$. The ridge size was $40 \mathrm{~cm}$, therefore the distance between the ridge was $20 \mathrm{~cm}$. The land ready for planting was fertilized by using goat manure with dose of $1 \mathrm{~kg} / \mathrm{m}^{2}$. After the age of $15 \mathrm{~d}$, the plants were fertilized by using the single inorganic fertilizer such as urea, TSP, KCl. Inorganic fertilizer at a dose of $270 \mathrm{~kg} /$ ha with a ratio of 4: 3: 2 was used. Liming was added prior to the planting.

Cutting was done in three different times, at ages of 85,95 , and $105 \mathrm{~d}$. Biomass obtained from the cutting was weighed to determine the total production per plot and the leaves, grains and stems were then separated and weighed.

Treatment combinations, between sorghum mutant lines and cutting ages are presented in Table 1. The design used in this study was split plot completely randomized design. The first factor was the type of sorghum as the main plot and the second factor was the age of cutting as a subplot.

\section{Chemical and Statistical Analyses}

Forage samples were dried under the sun and then dried by using oven with temperature of $60{ }^{\circ} \mathrm{C}$ for $48 \mathrm{~h}$ and then milled with sieve size $1.0 \mathrm{~mm}$. Analysis of dry matter, crude protein, crude fat and ash content was conducted by using AOAC method (2005). The digestibilities of dry matter and organic matter were analyzed by using the method of Tilley and Terry (1963). NH3 were analyzed by using Conway method (General Laboratory Procedures, 1966). Data were analyzed by using analysis of variance (ANOVA), if there was a significant different then the analyses was continued with DMRT (Duncan Multiple Range Test).

\section{RESULTS AND DISCUSSION}

\section{Biomass production}

The production of several types of dried sorghum in this study was obtained from the cutting ages of 85, 95 , and $105 \mathrm{~d}$. The production of sorghum in the form of dried leaves, stems and grains on each unit of the experiment is shown in Table 2. There was a high interaction $(\mathrm{P}<0.01)$ between cutting age and type of sorghum on production of leaf, stem, grain and biomass produc-

Table 1. Combination treatment between strains and age of cutting of sorghum

\begin{tabular}{lcccc}
\hline \multirow{2}{*}{ Cutting age } & \multicolumn{4}{c}{ Sorghum types } \\
\cline { 2 - 5 } & $(\mathrm{C} 1)$ & BMR(C2) & BMR (C3) & BMR (C4) \\
\hline 85 days (D1) & C1D1 & C2D1 & C3D1 & C4D1 \\
95 days (D2) & C1D2 & C2D2 & C3D2 & C4D2 \\
105 days (D3) & C1D3 & C2D3 & C3D3 & C4D3 \\
\hline
\end{tabular}

Note: C1= SAMURAI I M17; C2= PATIR 3.5 M7; C3= PATIR 3.6 M7; C4= PATIR 3.7 M7. 
tion. Biomass production increased with increasing age of cutting, and the genetic of sorghum was improved on production. Further test results showed significant differences $(\mathrm{P}<0.05)$ between treatments. Table 2 shows that the production of leaf, stem and grain BMR sorghum PATIR 3.5 increase with the increasing of cutting age, whereas variety SAMURAI I (M17), BMR sorghum PATIR 3.6 and PATIR 3.7, respectively show decreased productions of leaves and stems at cutting age of 105 days.

According to a genetic trait, sorghum variety of SAMURAI I (M17) has a bigger size when compared to the BMR sorghum, because the purpose of developing sorghum variety of SAMURAI I (M17) is for biofuel variety and it must be developed to have a higher biomass production. The results showed that sorghum variety of SAMURAI I (M17) produced higher leaf and stem than the BMR sorghum group. Sorghum variety of SAMURAI I (M17) had an average number of leaves of 11 leaf blades when cut, that was higher when compared with BMR sorghum (PATIR 3.5; PATIR 3.6; PATIR 3.7) that on average only had 8 leaf blades. This difference can cause the average production of dried leaves of sorghum variety of SAMURAI I (M17) higher than other types. The difference in the number of leaves in sorghum variety of SAMURAI I (M17) and sorghum Brown midrib can be caused by genetic difference. Sorghum SAMURAI type I (M17) also had an average height that was greater than $250 \mathrm{~cm}$ in the BMR sorghum when cut whereas Brown midrib sorghum types only have an average height of $160 \mathrm{~cm}$.

The effect of cutting on the leaf and stem productions of four types of sorghum can be caused by differences in timing of plant in entering the generative phase.BMR sorghum PATIR 3.5 is thought to have a long vegetative phase which tends to be varied so that at cutting age there are some plants that have entered the generative phase and there are still in the vegetative phase, causing some plants still continue to grow and develop. Observations in the field indicated that the growth of BMR sorghum PATIR 3.5 was more diverge in value than BMR sorghum PATIR 3.6 and PATIR 3.7. This difference may be related to the instability of these mutant lines.

The mean of grain production on all types of sorghum increased with the increased of the cutting age. Grain production was high at $105 \mathrm{~d}$ of cutting age because at this age the sorghum started entering the phase of optimal grain filling. At this phase the plant growth was concentrated on the formation of seeds, nutrients such as amino acids, sugars and proteins produced in the leaves and roots were transported to the seed and converted into starch and protein. Table 2 showed that there were significant differences in grain production $(\mathrm{P}<0.05)$ between the type of sorghum which may be caused by genetics difference. Sorghum from SAMURAI type I (M17) has a larger grain size when compared with all mutant lines of BMR sorghum. For this reason dry weight of grain SAMURAI I (M17) was higher when compared to the BMR sorghum.

Cutting age at $95 \mathrm{~d}$ gave the highest total biomass production for sorghum varieties of SAMURAI I (M17), BMR Sorghum PATIR 3.6 and BMR Sorghum PATIR 3.7 whereas BMR Sorghum PATIR 3.5 produced the highest biomass production at cutting age of $105 \mathrm{~d}$. Sorghum variety of SAMURAI I (M17) had the highest biomass production in all ages of BMR sorghum harvest compared. This difference can be caused by a higher stem size, larger grains as well as the number of leaves that much more than the BMR sorghum. This study showed that there was a significant differences $(\mathrm{P}<0.05)$ between $\mathrm{BMR}$ and non-BMR sorghum. The result of this study

Table 2. Production of leaves, stems, grain/plot and total production of biomass/plot (dry) at different cutting ages

\begin{tabular}{|c|c|c|c|c|}
\hline \multirow{2}{*}{ Variables } & \multirow{2}{*}{ Sorghum type } & \multicolumn{3}{|c|}{ Cutting age (Day) } \\
\hline & & 85 & 95 & 105 \\
\hline \multirow[t]{4}{*}{ Leaf (kg) } & SAMURAI I M17 & $2.63 \pm 0.24^{\mathrm{ef}}$ & $4.36 \pm 0.40^{\mathrm{a}}$ & $3.07 \pm 0.05^{c}$ \\
\hline & PATIR 3.5 & $2.08 \pm 0.33^{g}$ & $2.58 \pm 0.24^{\mathrm{ef}}$ & $2.99 \pm 0.09^{\mathrm{cd}}$ \\
\hline & PATIR 3.6 & $3.46 \pm 0.06^{\mathrm{b}}$ & $3.03 \pm 0.20^{c}$ & $1.31 \pm 0.06^{\mathrm{i}}$ \\
\hline & PATIR 3.7 & $2.28 \pm 0.04^{\mathrm{fg}}$ & $2.67 \pm 0.07^{\mathrm{de}}$ & $1.69 \pm 0.14^{\mathrm{h}}$ \\
\hline \multirow[t]{4}{*}{ Stem $(k g)$} & SAMURAI I M17 & $6.00 \pm 0.23^{\mathrm{a}}$ & $6.01 \pm 0.21^{\mathrm{a}}$ & $4.93 \pm 0.19^{c}$ \\
\hline & PATIR 3.5 & $1.82 \pm 0.21^{\mathrm{h}}$ & $3.10 \pm 0.35^{\mathrm{f}}$ & $3.87 \pm 0.13^{e}$ \\
\hline & PATIR 3.6 & $2.72 \pm 0.16^{\mathrm{g}}$ & $4.73 \pm 0.05^{\mathrm{cd}}$ & $2.78 \pm 0.18^{\mathrm{g}}$ \\
\hline & PATIR 3.7 & $3.40 \pm 0.13^{\mathrm{f}}$ & $5.65 \pm 0.05^{\mathrm{b}}$ & $4.47 \pm 0.04^{\mathrm{d}}$ \\
\hline \multirow[t]{4}{*}{ Grain (kg) } & SAMURAI I M17 & $0.52 \pm 0.01^{\mathrm{h}}$ & $1.11 \pm 0.007^{\mathrm{e}}$ & $2.17 \pm 0.09^{a}$ \\
\hline & PATIR 3.5 & $0.26 \pm 0.03^{\mathrm{i}}$ & $0.55 \pm 0.04^{\mathrm{h}}$ & $1.53 \pm 0.03^{c}$ \\
\hline & PATIR 3.6 & $0.16 \pm 0.03^{j}$ & $0.88 \pm 0.08^{\mathrm{f}}$ & $1.79 \pm 0.04^{\mathrm{b}}$ \\
\hline & PATIR 3.7 & $0.24 \pm 0.01^{\mathrm{ij}}$ & $0.69 \pm 0.008^{\mathrm{g}}$ & $1.22 \pm 0.05^{\mathrm{d}}$ \\
\hline \multirow[t]{4}{*}{ Total biomass production $(\mathrm{kg})$} & SAMURAI I M17 & $9.16 \pm 0.15^{c}$ & $11.48 \pm 0.58^{\mathrm{a}}$ & $10.19 \pm 0.14^{\mathrm{b}}$ \\
\hline & PATIR 3.5 & $4.17 \pm 0.39 \mathrm{~g}$ & $6.24 \pm 0.62^{\mathrm{f}}$ & $8.40 \pm 0.01^{\mathrm{d}}$ \\
\hline & PATIR 3.6 & $6.36 \pm 0.23^{f}$ & $8.65 \pm 0.32^{\mathrm{cd}}$ & $5.89 \pm 0.29^{f}$ \\
\hline & PATIR 3.7 & $5.93 \pm 0.12^{\mathrm{f}}$ & $9.02 \pm 0.14^{c}$ & $7.39 \pm 0.25^{\mathrm{e}}$ \\
\hline
\end{tabular}

Note: Means in the same line and column with different superscripts differ significantly $(\mathrm{P}<0.05)$. 
Table 3. Nutrient content of sorghum cutting at different ages (based on $100 \%$ dry matter)

\begin{tabular}{|c|c|c|c|c|c|}
\hline \multirow{2}{*}{ Variables } & \multirow{2}{*}{ Sorghum type } & \multicolumn{3}{|c|}{ Cutting age (Day) } & \multirow{2}{*}{ Average } \\
\hline & & 85 & 95 & 105 & \\
\hline \multirow[t]{5}{*}{ Ash (\%) } & SAMURAI I M17 & $5.53 \pm 0.37$ & $7.57 \pm 2.87$ & $6.79 \pm 0.70$ & $6.63 \pm 1.02$ \\
\hline & PATIR 3.5 & $6.08 \pm 0.17$ & $7.19 \pm 1.82$ & $9.53 \pm 3.04$ & $7.60 \pm 1.75$ \\
\hline & PATIR 3.6 & $5.71 \pm 0.37$ & $9.75 \pm 3.83$ & $6.77 \pm 0.89$ & $7.41 \pm 2.09$ \\
\hline & PATIR 3.7 & $5.26 \pm 0.85$ & $9.44 \pm 3.02$ & $5.68 \pm 0.55$ & $6.80 \pm 2.29$ \\
\hline & Average & $5.65 \pm 0.34^{b}$ & $8.49 \pm 1.29^{a}$ & $7.19 \pm 1.64^{\mathrm{ab}}$ & \\
\hline \multirow[t]{5}{*}{ Crude fiber (\%) } & SAMURAI I M17 & $31.90 \pm 1.27$ & $34.78 \pm 2.27$ & $31.39 \pm 2.48$ & $32.69 \pm 1.82$ \\
\hline & PATIR 3.5 & $32.31 \pm 1.34$ & $33.36 \pm 2.64$ & $30.94 \pm 0.98$ & $32.20 \pm 1.20$ \\
\hline & PATIR 3.6 & $32.07 \pm 0.39$ & $31.12 \pm 4.54$ & $33.40 \pm 0.95$ & $32.20 \pm 1.14$ \\
\hline & PATIR 3.7 & $33.36 \pm 3.57$ & $31.50 \pm 0.79$ & $35.21 \pm 0.71$ & $33.36 \pm 1.85$ \\
\hline & Average & $32.41 \pm 0.65$ & $32.69 \pm 1.70$ & $32.74 \pm 1.97$ & \\
\hline \multirow[t]{5}{*}{ Crude fat (\%) } & SAMURAI I M17 & $1.09 \pm 0.07$ & $0.63 \pm 0.29$ & $0.40 \pm 0.24$ & $0.70 \pm 0.35^{\mathrm{ab}}$ \\
\hline & PATIR 3.5 & $0.58 \pm 0.19$ & $0.34 \pm 0.21$ & $1.04 \pm 0.71$ & $0.65 \pm 0.35^{\mathrm{b}}$ \\
\hline & PATIR 3.6 & $1.47 \pm 0.10$ & $0.56 \pm 0.39$ & $1.07 \pm 0.26$ & $1.03 \pm 0.45^{\mathrm{a}}$ \\
\hline & PATIR 3.7 & $0.88 \pm 0.35$ & $0.38 \pm 0.21$ & $1.84 \pm 0.71$ & $1.03 \pm 0.74^{\mathrm{a}}$ \\
\hline & Average & $1.00 \pm 0.38^{\mathrm{a}}$ & $0.48 \pm 0.14^{b}$ & $1.09 \pm 0.59^{\mathrm{a}}$ & \\
\hline \multirow[t]{5}{*}{ NFE (\%) } & SAMURAI I M17 & $46.78 \pm 1.52$ & $46.84 \pm 5.11$ & $49.47 \pm 2.27$ & $47.70 \pm 1.53$ \\
\hline & PATIR 3.5 & $43.92 \pm 1.02$ & $46.06 \pm 3.51$ & $47.79 \pm 3.10$ & $45.92 \pm 1.93$ \\
\hline & PATIR 3.6 & $46.13 \pm 1.74$ & $46.27 \pm 2.24$ & $46.42 \pm 1.29$ & $46.27 \pm 0.14$ \\
\hline & PATIR 3.7 & $45.86 \pm 4.75$ & $44.56 \pm 1.56$ & $45.92 \pm 2.81$ & $45.45 \pm 0.76$ \\
\hline & Average & $45.67 \pm 1.22$ & $45.93 \pm 0.97$ & $47.40 \pm 1.59$ & \\
\hline \multirow[t]{4}{*}{ Crude protein (\%) } & SAMURAI I M17 & $14.70 \pm 0.41^{\mathrm{ab}}$ & $10.19 \pm 1.39^{d}$ & $11.95 \pm 0.54^{\mathrm{bcd}}$ & $10.89 \pm 3.51$ \\
\hline & PATIR 3.5 & $17.11 \pm 0.66^{\mathrm{a}}$ & $13.05 \pm 1.05^{\mathrm{bc}}$ & $10.70 \pm 0.10^{\mathrm{cd}}$ & $13.62 \pm 3.24$ \\
\hline & PATIR 3.6 & $14.62 \pm 1.74^{\mathrm{ab}}$ & $12.31 \pm 3.55^{\mathrm{bcd}}$ & $12.34 \pm 0.76^{\mathrm{bcd}}$ & $13.09 \pm 1.32$ \\
\hline & PATIR 3.7 & $14.64 \pm 1.27^{\mathrm{ab}}$ & $14.12 \pm 1.18^{\mathrm{b}}$ & $11.35 \pm 1.20^{\mathrm{cd}}$ & $13.37 \pm 1.76$ \\
\hline \multirow[t]{4}{*}{ TDN (\%) } & SAMURAI I M17 & $45.48 \pm 0.36^{\mathrm{abcd}}$ & $44.30 \pm 2.40^{\mathrm{bcd}}$ & $47.39 \pm 1.29^{\mathrm{abc}}$ & $44.83 \pm 0.59$ \\
\hline & PATIR 3.5 & $50.49 \pm 0.51^{\mathrm{a}}$ & $48.31 \pm 0.77^{\mathrm{ab}}$ & $40.99 \pm 4.78^{\mathrm{de}}$ & $46.59 \pm 4.97$ \\
\hline & PATIR 3.6 & $42.63 \pm 1.98^{\mathrm{cd}}$ & $46.18 \pm 4.38^{\mathrm{abcd}}$ & $43.15 \pm 2.44^{\text {bcd }}$ & $43.98 \pm 1.91$ \\
\hline & PATIR 3.7 & $46.67 \pm 3.06^{\mathrm{abc}}$ & $48.26 \pm 0.49^{\mathrm{ab}}$ & $37.11 \pm 5.12^{\mathrm{e}}$ & $44.01 \pm 6.03$ \\
\hline
\end{tabular}

Note: Means in the same line and column with different superscripts differ significantly $(\mathrm{P}<0.05)$.

Estimation of TDN by Hartadi (1980) formula:

$\mathrm{TDN}=92.464-(3.338 \times \mathrm{CF})-(6.945 \times \mathrm{EE})-(0.762 \times \mathrm{NFE})+(1.115 \times \mathrm{CP})+(0.031 \times \mathrm{CF} 2)-(0.133 \times \mathrm{EE} 2)+(0.036 \times \mathrm{CF} \times \mathrm{NFE})+(0.207 \times \mathrm{EE} \times \mathrm{NFE})+$ $(0.1 \times \mathrm{EE} \times \mathrm{CP})-(0.022 \times \mathrm{EE} \times \mathrm{CP})$.

similar to that reported by Oliver et al. (2005) that BMR sorghum have lower biomass production than non-BMR sorghum.

\section{Nutrient Content}

The quality of forage is indicated by the content of nutrients such as ash, crude fat, crude fiber, crude protein, TDN and Nitrogen free extract. Results of analysis of nutrient content of four types of sorghum cut at different ages are presented in Table 3. There was a significant interaction $(\mathrm{P}<0.05)$ between age and type of sorghum cutting on the percentage of TDN, lignin, and crude protein. The cutting age gave significant effect $(\mathrm{P}<0.05)$ on ash content and crude fat but it did not significantly affect crude fiber content.

Table 3 showed that there was no significant difference in TDN values, from the age of 85-105 d sorghum variety of SAMURAI I (M17) and BMR Sorghum PATIR 3.6, whereas the BMR Sorghum PATIR 3.5 and BMR
Sorghum PATIR 3.7 showed the significant decrease in TDN values $(\mathrm{P}<0.05)$ at the cutting age of $105 \mathrm{~d}$. The low TDN value may be related to the continued increase in lignin content as the cutting age increases. The highest TDN value of BMR Sorghum PATIR 3.5 (BMR) was found at cutting age of $85 \mathrm{~d}$. The high value of TDN in BMR sorghum PATIR 3.5 cut at $85 \mathrm{~d}$ of age was assumed to be caused by the low percentage of lignin content that increased the fiber digestibility.

The content of crude protein in BMR Sorghum PATIR 3.5 and BMR SorghumPATIR 3.7 decreased significantly $(\mathrm{P}<0.05)$ with the increased cutting age. The longer the cutting age, the lower the crude protein content. The same results were reported by Mansyur et al. (2005), that the longer the interval of cutting the lower the crude protein content. The highest crude protein content of all types of sorghum was obtained at cutting age of 85 days when the sorghum began to enter the flowering phase. According to the research reported by Nabi et al. (2006) the sorghum cut at flowering stage had 
Tabel 4. Dry matter digestibility (DMD), organic matter digestibility (OMD), and N-ammonia concentrations of sorghum cutting at different ages

\begin{tabular}{|c|c|c|c|c|}
\hline \multirow{2}{*}{ Variables } & \multirow{2}{*}{ Sorghum type } & \multicolumn{3}{|c|}{ Cutting age (day) } \\
\hline & & 85 & 95 & 105 \\
\hline \multirow[t]{4}{*}{$\mathrm{DMD}(\%)$} & SAMURAI I (M17) & $61.29 \pm 2.82^{\mathrm{abcd}}$ & $56.26 \pm 1.62^{\text {cdef }}$ & $40.29 \pm 1.64^{g}$ \\
\hline & PATIR 3.5 & $64.98 \pm 5.97^{\mathrm{ab}}$ & $50.97 \pm 0.82^{\text {ef }}$ & $48.99 \pm 4.72^{\mathrm{f}}$ \\
\hline & PATIR 3.6 & $67.44 \pm 8.27^{\mathrm{a}}$ & $55.26 \pm 1.57^{\text {def }}$ & $54.08 \pm 1.90^{\mathrm{def}}$ \\
\hline & PATIR 3.7 & $64.58 \pm 2.48^{\mathrm{abc}}$ & $57.49 \pm 5.43^{\text {bcde }}$ & $57.90 \pm 7.73^{\text {bcde }}$ \\
\hline \multirow[t]{4}{*}{ OMD (\%) } & SAMURAI I (M17) & $60.78 \pm 2.95^{\mathrm{abc}}$ & $56.25 \pm 1.40^{\text {bcde }}$ & $39.60 \pm 0.99^{f}$ \\
\hline & PATIR 3.5 & $64.32 \pm 6.46^{\mathrm{ab}}$ & $50.95 \pm 1.34^{\mathrm{de}}$ & $47.96 \pm 4.95^{\mathrm{de}}$ \\
\hline & PATIR 3.6 & $66.04 \pm 9.20^{\mathrm{a}}$ & $54.76 \pm 1.57^{\text {cde }}$ & $53.85 \pm 2.64^{\text {cde }}$ \\
\hline & PATIR 3.7 & $64.19 \pm 2.60^{\mathrm{ef}}$ & $57.03 \pm 5.23^{\text {cde }}$ & $56.91 \pm 7.70^{\text {cde }}$ \\
\hline \multirow[t]{4}{*}{$\mathrm{NH}_{3}(\mathrm{mM})$} & SAMURAI I (M17) & $9.65 \pm 0.33^{\mathrm{a}}$ & $9.26 \pm 1.52^{\mathrm{a}}$ & $6.01 \pm 1.14^{c}$ \\
\hline & PATIR 3.5 & $9.13 \pm 0.03^{\mathrm{a}}$ & $6.87 \pm 0.36^{\mathrm{bc}}$ & $5.97 \pm 0.61^{c}$ \\
\hline & PATIR 3.6 & $8.29 \pm 1.76^{\mathrm{ab}}$ & $6.55 \pm 1.20^{\mathrm{bc}}$ & $5.41 \pm 1.03^{c}$ \\
\hline & PATIR 3.7 & $9.40 \pm 1.91^{\mathrm{a}}$ & $8.94 \pm 0.92^{\mathrm{a}}$ & $5.43 \pm 0.71^{\mathrm{c}}$ \\
\hline
\end{tabular}

Note: Means in the same line and column with different superscripts differ significantly $(\mathrm{P}<0.05)$.

a higher crude protein than that cut in the next phase. The result of this study was similar to that reported by Colombo et al. (2007) that BMR sorghum had higher crude protein than non-BMR sorghum.

\section{Dry Matter Digestibility (DMD), Organic Matter Digestibility (OMD) and N-ammonia Concentrations of Sorghum.}

The average value of dry matter digestibility (DMD), organic matter digestibility (OMD) and $\mathrm{N}$-ammonia concentrations are shown in Table 4 . There were significant interaction $(\mathrm{P}<0.05)$ between cutting age and type of sorghum on dry matter digestibility (DMD), organic matter digestibility (OMD) and the concentration of $\mathrm{N}$-ammonia.

The dry matter digestibility and organic matter digestibility decreased in line with sorghum cutting age. The highest dry matter digestibility and organic matter digestibility of all types of sorghum was obtained at the cutting age of $85 \mathrm{~d}$. The decreased digestibility of sorghum with the increased time of cutting age can be caused by the increased lignin content. According to Jayanegara et al. (2009), digestibility value is strongly affected by the lignin content that one of component of the ADF (Acid Detergent Fiber). The high lignin content inhibits digestion by rumen microbes.

The mean values of digestibility of BMR Sorghum PATIR 3.5, BMR Sorghum PATIR 3.6 and BMR Sorghum 3.7 which were higher than the variety of SAMURAI I (M17) was also caused by the possibility of lower lignin content of these lines. As reported by Oliver et al. (2004) and Vogler et al. (2009) that the percentage of sorghum BMR has a lower lignin content than non-BMR.

Mean concentrations of $\mathrm{N}$-ammonia is shown in Table 4. N-ammonia concentration decreased as cutting age increased, this result could be associated with crude protein content in plants. The longer the cutting age the lower the crude protein content so that less protein that is available to the rumen microbes.

\section{CONCLUSION}

Non BMR sorghum variety of SAMURAI I (M17) achieved optimal biomass production and Nutrient Content at cutting age of 85 days similar to BMR sorghum mutant lines PATIR 3.6 and PATIR 3.5, whereas BMR sorghum mutant lines of PATIR 3.7 achieved optimum production at the age of 95 days of cutting. All types of sorghum varieties were not recommended to be cut at $105 \mathrm{~d}$.

\section{ACKNOWLEDGEMENT}

Thanks to SEAMEO BIOTROP, Joint FAO/IAEA Division and BATAN on procurement assistance of sorghum seed for this research.

\section{REFERENCES}

[AOAC] Association of Official Analytical Chemists. 2005. Official Methods of Analysis of AOAC International. 18th ed. Assoc. Off. Anal. Chem.,Arlington.

Colombo, D., Gm. Crovetto, S. Colombini, G. Galassi, \& L. Rapetti. 2007. Nutritive value of different hybrids of sorghum forage determined in vitro. Ital. J. Anim. Sci. 6: 289-291.

Dann, H. M., R. J. Grant, K. W. Cotanch, E. D. Thomas, C. S. Ballard, \& R. Rice. 2008. Comparison of brown midrib sorghum-sudang grass with corn silage on lactational performances and nutrient digestibility in Holstein dairy cows. J. Dairy. Sci. 91: 663-672. http://dx.doi.org/10.3168/ jds.2007-0521

General Laboratory Procedures. 1966. Department of Dairy Science.University of Wisconsin. Madison.

Godoy, J. G. V. \& T. T. Tesso. 2013. Analysis of Juice Yield, Sugar Content, and Biomass Accumulation in Sorghum. J. Crop Science. 53: 1288-1297. http://dx.doi.org/10.2135/cropsci2012.04.0217

Jayanegara, A., A. Sofyan, H. P. S. Makkar, \& K. Becker. 2009. Kinetika produksi gas, kecernaan bahan organik dan produksi gas metana in vitro pada hay dan jerami yang disuplementasi hijauan mengandung tanin. Med. Pet. 32:120-129. 
Mansyur, H. D., T. Dhalika, Hardjosoewignyo, \& L. Abdullah. 2005. Pengaruh interval pemotongan dan invasi gulma Choromolaena odorata terhadap produksi dan kualitas rumput Brachiaria humidicola. Med. Pet. 28:77-86.

Nabi, C. G., M. Riaz, \& G. Ahmad. 2006. Comparison of some advances lines of sorghum bicolor L. Monech for green fodder/dry matter yields and morpho-economic parameters. J. Agric. Res. 44(3).

Oliver, A. L., R. J. Grant, J. F. Pedersen, \& J. O'rear. 2004. Comparison of brown midrib- 6 and -18 forage sorghum with conventional sorghum and corn silage in diets of lactating dairy cows. J. Dairy Sci. 87:637-644. http://dx.doi. org/10.3168/jds.S0022-0302(04)73206-3

Oliver, A. L., J. F. Pedersen, R. J. Grant, \& T. J. Klopfenstein. 2005. Comparative effects of the sorghum bmr-6 and bmr-
12 genes: I. Forage sorghum yield and quality. J. Crop. Sci. 45: 2234-2239. http://dx.doi.org/10.2135/cropsci2004.0644

Tilley, J. M. A. \& R. A. Terry. 1963. A two stage technique for the in vitro digestion of foragecrops. J. Br. Grassland Soc. 18: 104-111. http://dx.doi.org/10.1111/j.1365-2494.1963. tb00335.x

Vasilakoglou, I., K. Dhima, N. Karagiannidis, \& T. Gatsis. 2011. Sweet sorghum productivity for biofuels under increased soil salinity and reduced irrigation. Field Crops Res. 120: 38-46. http://dx.doi.org/10.1016/j.fcr.2010.08.011

Vogler, R. K., T. T. Tesso, K. D. Johnson, \& G. Ejeta. 2009. The effect of allelic variation on forage quality of brown midrib sorghum mutants with reduced caffeic acid O-methyl transferase activity. African J. Biochemistry Research 3:070-076. 